\title{
Histochemical Study on the Bile Duct System of Normal Mongolian Gerbils
}

\author{
Shin-ichi ITAGAKI, Miguel A. PETRUCCELLI, and Kunio DOI \\ Department of Biomedical Science, Faculty of Agriculture, The University \\ of Tokyo, 1-1-1 Yayoi, Bunkyo-ku, Tokyo 113, Japan
}

(Received 17 August 1990/Accepted 23 October 1990)

\begin{abstract}
The bile duct system of normal Mongolian gerbils was examined histochemically. The luminal surface membrane and apical cytoplasm of the biliary and gallbladder epithelial cells were stained with periodic acid-Schiff (PAS), alcian blue, $\mathrm{pH} 2.5(\mathrm{AB})$ and high iron diamine (HID)- $\mathrm{AB}$, and many epithelial cells of the common bile duct and gallbladder had weakly PAS-positive granular material in their supranuclear cytoplasm. Lectin-histochemiaclly, these cells had binding sites to Concanavalia ensiformis (ConA), Dolichos biflorus (DBA), Glycine max (SBA), Ulex europeas $I$ (UEA-I), and Triticum vulgaris (WGA), On the other hand, the periductal glandular epithelial cells were not stained by any histochemical stainings. In addition to these light microscopic findings, the electron microscopic findings based on the periodic acid-silver methenamine method and avidinbiotin colloidal gold method for DBA and WGA suggested that the biliary and gallbladder epithelial cells of Mongolian gerbils secreted mucin with terminal sialic and sulfonic acid residues and that the lectin binding activity of mucin secreted from these cells was similar to that of mucin secreted from the periductal glandular epithelial cells of mice and rats.
\end{abstract}

Mucin secreted from the epithelial cells of the bile duct system has been reported to play an important role in a formation of gall stones in man $[16,27]$, and many biochemical data of mucin secreted into the bile duct were proposed $[5,10,15,17]$. Histochemical studies on the distribution or alteration of glycoproteins including mucin in the bile duct system were also carried out under physiological or pathological conditions [13,23-25]. More recently, lectins have been attracting great attention as a useful tool for the histochemical analysis of glycoproteins in various tissues $[6,8,9]$.

Mongolian gerbils have been established as one of the most popular laboratory animals, and now they are known to be useful as a experimental model of lithiasis [3]. However there are only few reports of histochemical characteristics of glycoproteins in the bile duct system of Mongolian gerbils [26]. The purpose of this study is to clarify the histochemical characteristics of glycoproteins in the bile duct system of normal Mongolian gerbils and to compare it with those of mice and rats previously reported $[11,12]$.

\section{Materials and Methods}

Animals : 12 8-week-old Mongolian gerbils of the Tumble Brook strain ( 6 males and 6 females ; weighing 50-70g) were kindly offered by Prof. Dr. K. Mochizuki, Department of Laboratory Animal Science, Nihon University. Animals had been housed in an animal room under controlled condition and fed MF pellets (Oriental Yeast Co. Ltd., Tokyo) and water ad libitum. They were sacrificed by exanguination under ether anesthesia one day after their arrival in our laboratory. Immediately after sacrifice, the liver, gallbladder and common bile duct were took out from each animal and subjected to the following examinations.

Histochemical procedures: The liver, gallbladder and common bile duct were fixed with 


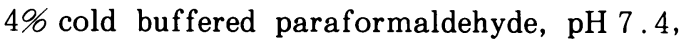
for $24 \mathrm{~h}$. Serial $4 \mathrm{um}$-paraffin sections were cut and stained with hematoxylin and eosin (HE). In addition, the following staining procedures were also employed : periodic acidSchiff (PAS) reaction with or without alphaamylase (Sigma Co., St. Louis, (MO) - pretreatment [21], alcian blue, $\mathrm{pH} 2.5(\mathrm{AB})$ and high iron diamine (HID) - $\mathrm{AB}$ sequence with or without neuraminidase pretreatment[20]. Neuraminidase (Nakarai Chemicals Co., Kyoto) is originated from Arthrobactor ureafaciens.

Lectin-histochemical procedures: The remainig sections made for the above-mentioned histochemical examination were stained with Dolichos biflorus (DBA), Griffonia simplicifolia-I (GS-I), GS-II, Glycine max (SBA), Arachis hypogaea (PNA), Ulex europeus-I (UEA-I) and Triticum vulgaris (WGA) (horseradish peroxidase conjugated form ; $\mathrm{E}-\mathrm{Y}$ Laboratories, San Mateo, CA) according to the previously reported procedures [12] and with Concanavalia ensiformis (Con A) (horseradish peroxidase-unconjugated form ; Sigma, USA) according to the method of Bernhard and Avameas [4]. Histochemical control staining was also carried out as reported before [12].

In order to remove terminal sialic acid residues, sections were digested with neuraminidase before staining with PNA lectin as reported before [12] .

Periodic acid-silver methenamine (PAM) method : Small pieces of the gallbladder and common bile duct were fixed with $4 \%$ cold glutaraldehyde in phosphate buffer $(\mathrm{pH} 7.7)$ for 2 $\mathrm{h}$, post-fixed with $1 \%$ cold osmium tetroxide in the same buffer for $2 \mathrm{~h}$, dehydrated and embedded in Quetol 812 (Nisshin EM, Tokyo). Thin sections mounted on the nickel grids were stained by PAM method in order to detect intracellular localization of glycoproteins [19] . Some sections were mounted on copper grids and stained routinely with uranyl acetate and lead citrate. These sections were observed under JEOL's model JEM $1200 \mathrm{EX}$ electron microscope (JEOL, Tokyo).

Avidin-biotin colloidal gold (ABG) method : Small pieces of the gallbladder and common bile duct were fixed with $4 \%$ cold bufferd paraformaldehyde solution, $\mathrm{pH} 7.4$, for 4 $\mathrm{h}$, dehydrated and embedded in Lowicryl K4M (Polyscience, Warrington, PA) according to the rapid method of Altman et al. [1]. Ultra- thin sections mounted on nickel grids were treated with $1 \%$ bovine serum albumin (BSA) in PBS for $15 \mathrm{~min}$ and incubated with $15 \mathrm{ug} / \mathrm{ml}$ of biotinylated DBA or WGA (E-Y Laboratories) in PBS containing $0.1 \%$ BSA for $1 \mathrm{~h}$ and tenfold-diluted streptavidin gold (granule size, $15 \mathrm{~nm}$ : Janssen, Belgium) for $30 \mathrm{~min}$. Then they were stained with uranyl acetate and lead citrate, dried and served for observation under electron microscope.

\section{Results}

Histological findings: The intrahepatic and common bile ducts and gallbladder of Mongolian gerbils were lined with flattened to cuboidal, cuboidal, and cuboidal to low columner epithelium, respectively. The large intrahepatic and common bile ducts had a small number of periductal glands. Many blebs were observed on the surface of epithelial cells, especially in the common bile duct.

Histochemical findings: The luminal surface membrane and apical cytoplasm of the biliary and gallbladder epithelial cells were positive for PAS, AB and HID-AB (Figs. 1,2). Many epithelial cells of the common bile duct and gallbladder had weakly PAS-positive granular material in their supranuclear cytoplasm. These granules were completely negative for $\mathrm{AB}$ and $\mathrm{HID}-\mathrm{AB}$. Some blebs were also stained with $\mathrm{PAS}, \mathrm{AB}$ and $\mathrm{HID}-\mathrm{AB}$.

The stainability of the above-mentioned cellular structures for PAS and HID-AB disappeared after alpha-amylase and neuraminidase digestion, respectively. The stainability for $A B$ decreased after neuraminidase digestion.

On the other hand, the periductal glandular epithelial cells were not stained with PAS, AB and HID-AB.

Lectin-histochemical findings : Lectin-bin ding activities in the biliary and gallbladder epithelial cells are shown in Table 1. No lectin bound to the periductal glandular epithelial cells. In the epithelial cells of the common bile duct and gallbladder, Con A, DBA, SBA and UEA-I bound to the luminal surface membrane, apical cytoplasm including blebs and supranuclear cytoplasm (Figs. 3-6). Among these 4 lectins, SBA showed the weakest binding activity to the supranuclear cytoplasm. WGA bound to the luminal surface membrane and apical cytoplasm (Fig. 7 ). After neuramini- 
dase-digestion, PNA became to bind to the luminal surface membrane and apical cytoplasm (Fig. 8).

Ultrastructural findings: The biliary and gallbladder epithelial cells had many villi on their luminal surface and they had many mitochondria, rough endoplasmic reticula ( $\mathrm{rER}$ ) and vesicles and well-developed Golgi apparatus in their cytoplasm.

The cell membrane, vesicles, ribosomes and Golgi apparatus were positively stained by PAM method (Fig. 9). Trans-cisternae of Golgi apparatus were more strongly positive than cis-cisterna (Fig. 10). Blebs contained many vesicles and other intracytoplasmic organella which were also positively stained by PAM method (Fig. 11).

The binding activity to DBA and WGA was detected in the villi and vesicles (Fige. 12, 13). No gold particle was observed in Golgi apparatus when WGA was applied (Fig. 12), while many gold particles were found in Golgi area of some cells when DBA was applied (Fig. 14).

\section{Discussion}

Mucin in the bile duct system is mainly secreted from epithelial cells of the periductal glands in mice [12] and from goblet cells of the periductal glands in rats[11]. In.Mongolian gerbils, epithelial cells of the biliary tract and gallbladder exhibited positive reaction to most of basical and lectin histochemical stainings, while those of the periductal glands showed no positive reaction to these stainings. The biliary and gallbladder epithelial cells had many vesicles and $\mathrm{rER}$ and well developed Golgi apparatus, which were positively stained by PAM method. These findings suggest that the epithelial cells of the biliary tract and gallbladder instead of those of the periductal glands play an important role in mucin-secretion in the bile duct system of Mongolian gerbils. Furthermore, except for GS-II, lectin-histochemical characteristics of the mucin was similar to those of the mucin secreted from the periductal glandular epithelial cells of mice and rats (Table 1). Proposal histological sites of mucinsecretion in the bile duct system of three rodents are shown in Fig. 15.

Lee [14] reported that active secretion of glycoprotein droplets was observed electron microscopically in the gallbladder epithelium of other animal species. In this regard, judging from the histochemical characteristics and ultrastructural PAM-stainability of blebs, it is considered in Mongolian gerbils that mucin might be secreted together with a part of cytoplasm by means of apocrine secretion. However, "pinching off" process which is a morphological evidence of apocrine secretion was not detected in the present material.

In comparison with Con A, SBA and UEAI, WGA did not bind to the supranuclear cytoplasm of the biliary tract and gallbladder epithelial cells, and this means that Golgi apparatus of these cells had little binding sites to

Table 1. Lectin reactivities in the bile duct system*

\begin{tabular}{|c|c|c|c|c|c|c|c|c|c|}
\hline & ConA & $\mathrm{DBA}$ & GS- & GS-II & PNA & $e^{a}-\mathrm{P}$ & SBA & UEA- & WGA \\
\hline \multicolumn{10}{|l|}{$\begin{array}{l}\text { Biliary and } \\
\text { gallbladder } \mathrm{ec}^{\mathrm{b}}\end{array}$} \\
\hline luminal surface membrane & 2 & 3 & 0 & 0 & 0 & 2 & 3 & 2 & 3 \\
\hline apical cytoplasm ${ }^{c}$ & $0-2$ & $0-3$ & 0 & 0 & 0 & $0-2$ & $0-2$ & $0-3$ & $0-2$ \\
\hline supranuclear region & $0-3$ & $0-3$ & 0 & 0 & 0 & 0 & $0-2$ & $0-3$ & 0 \\
\hline Mouse glandular $\mathrm{ec}^{\mathrm{d}}$ & 2 & 2 & 0 & 2 & 0 & 0 & 2 & 2 & 2 \\
\hline Rat goblet celle & $0-1$ & 2 & 0 & $0-2$ & 0 & $0-1$ & $1-2$ & $0-2$ & 2 \\
\hline
\end{tabular}

* Numbers indicate staining intensity on a subjectively estimated scale from 0 , unreactive to 3 , most reactive. A $0-1$ or $0-2$ indicates heterogeneity in staining, with a subpopulation of cells being unstained and the remainder varying in reactivity from $1-2 . \quad{ }^{a} \mathrm{Neu}=$ Neuraminidase ${ }^{\mathrm{b}} \mathrm{ec}=$ epithelial cell c apical cytoplasm includes cytoplasm within bleb on luminal surface of both cells. d $[11,12] \quad$ e $[11]$ 
RAT BILE
DUCT
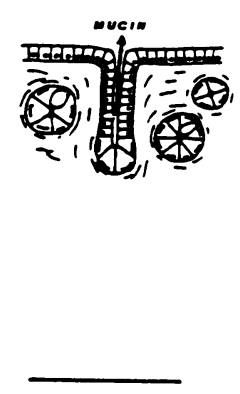

GERBIL

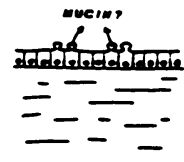

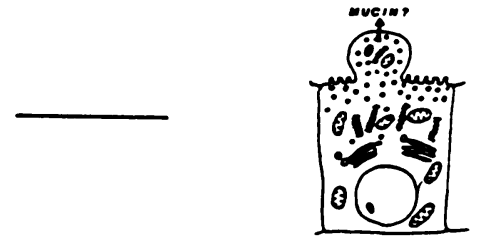

MOUSE

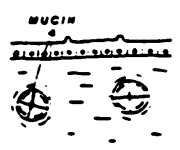

\section{GALL - BLADDER}

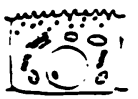

Fig. 15. Proposal histological sites of secreting mucin in the bile duct system of three rodents

WGA as indicated by lectin-cytochemical findings and PAM-stainability.

From the findings of $\mathrm{AB}^{-}, \mathrm{HID}-\mathrm{AB}-$ and PNA-stainability after neuraminidase digestion, mucin secreted in the bile duct system of Mongolian gerbils is thought to have terminal sialic acid residues, one of sugars specific to WGA, as well as terminal sulfonic acid residues [26]. Terminal sialic acid residues might be added carbohydrate side chains in the final process of glycosilation at Golgi apparatus and Golgi-derived secretory granules [2]. On the other hand, a wide-range lectin-binding activity of mucin may reflect that mucin consists of large molecular polymers with various carbohydrate side chains [17].

In the intestine of man, PNA receptors in the mucous epithelium are visualized after neuraminidase digestion under normal conditions and they are demonstrated without neuraminidase pretreatment only under precancerous or cancerous conditions $[7,28]$. On the other hand, in the gallbladder of man, it is reported that PNA receptors were expressed in the epithelium under normal conditions without neuraminidase-pretreatment [13]. The epithelial cells of the biliary tract and gallbladder of Mongolian gerbils exhibited similar PNA stainability to that of the epithelial cells of the normal intestine of man. Surface glycoprotein may bave penultimate residues with PNA receptors under terminal sialic acid [6] .

In man, UEA-I receptors are normally expressed in the gallbladder epithelial cells as well as the epithelial cells in the caecum and ascending colon, and various changes of UEA-I receptors are brought about during the process of canceration [13,22]. In Mongolian gerbils, it was also clarified in the present study that UEA-I receptors existed normally in the biliary and gallbladder epithelial cells.

In conclusion, the epithelial cells of the biliary tract and gallbladder of Mongolian gerbil might play an important role in the secretion of mucin with terminal sialic and sulfonic acid residues which exhibihed similar lectinbinding activity to that of mucin secreted from the periductal glands of mice and rats.

The authors wish to express their gratitude to Prof. Dr. K. Mochizuki, Department of Laboratory Animal Science, Nihon University, for his kind offer of animals and to Drs. Mari Norimatsu and Chiyo Doi for their technical assistance. One of the authors, M. A. Petruccelli, is a research fellow from National University of La Plata, Argentina, financially supported by JICA (Japan International Cooperation Agency).

\section{References}

[1] Altman, L. G., Schneidr, B. G., and Papermaster, D. S. (1984). Rapid embedding of tissues in Lowicryl K4M for immunoelectron microscopy. J. Histochem Cytochem 32, 1217-1223.

[2] Bennet, G (1984). Role of the Golgi complex in the secretory process. In Cell biology of the secretory process, pp. 102-147, Cantin, M., and Montreal, Q. (eds.), Karger, Basel.

[3] Bergman, F. and van der Linden, W. (1971). Reaction of the gerbil to cholesterol-cholic acid-containing gallstone inducing diet. Acta Pathol Micro biol Scand A,79, 476-486. 
[4] Bernhard, W. and Avameas, S. (1971). Ultrastructural visualization of cellular carbohydrate components by means of Concanavalin A. Exp. Cell Res., 64, 232-236.

[5] Bouchier, I. A. D. and Clamp, J. R. (1971). Glycoproteins in human bile. Clin Chlm Acta, 35, 219224.

[6] Cooper, H. S. (1984). Lectins as probes in histochemistry and immunohistochemistry : the peanut (Arachis hypogaea) lectin. Human Pathol, 15, 904-906.

[ 7 ] Cooper, H. S., Ferano. P., and Coapman, R. A. (1987). Peanut lectin binding sites in colons of patients with ulcerative colitis. Arch Pathol Lab. Med, 111, 270-275.

[8] Damjanov, I. (1986). Lectins as surrogates for the water of castalia : for the anatomist, pathologist, or both. Ultrastruct. Pathol, 10, 3-7.

[9] Damjanov, I. (1987). Biology of disease : lectin cytochemistry and histochemistry. Lab. Invest., 57, 5-20.

[10] Harvey, P. R. C., Rupar, C. A., Gallinger, S., Petrunka, C. N., and Strasberg, S. M. (1986). Quantative and qualitative comparison of gall bladder mucous glycoprotein from patients with and without gall stones. Gut, 27, 374-381.

[11] Itagaki, S., Doi, C., Mitsuoka, T., and Doi, K. (1990). Histochemical study on the bile duct system of normal rat. Exp. Anim, 39, 421-424.

[12] Itagaki, S., Honjo, K., Doi, K., and Mitsuoko, T. (1988). Histochemical characteristics of glycoproteins in the bile duct system of mice immunized with swine serum. Histochem, 90, 207-214.

[13] Karayannopoulou, G. and Damjanov, I. (1987). Lectin binding sites in the human gallbladder and cystic duct. Histochem, 88, 75-83.

[14] Lee, S. P. (1980). The mechanism of mucus secretion by the gallbladder epithelium. Br. J. Exp. Pathol, 61, 117-119.

[15] Lee, S. P., Lim, T. H., and Scott, A. J. (1979). Garbohydrate moieties of glycoproteins in human hepatic and gall-bladder bile, gall-bladder mucosa and gall stones. Clin Sci, 56, 533-538.

[16] Levy, P. F., Smith, B. F., and LaMont J. T. (1984). Human gallbladder mucin accelerates nucleation of cholesterol in artificial bile. Gastroenterol, 87, 270275 .

[17] Pearson, J. P., Kaura, R., Taylor, W., and Allen, A.
(1982). The compositon and polymeric structure of mucus glycoprotein from human gallbladder bile. Biochim Biophys. Acta, 706, 221-228.

[18] Peters, B. P., Ebisu, S., Goldstein, I. J., and Flahner, M. (1979). Interaction of weat germ agglutinin with sialic acid. Biochem, 18, 5505-5511.

[19] Rambourg, A. (1967). An improved silver methenamine technique for the detection of periodic acid reactive complex carbohydrates with the elctron microscope. J. Histochem Cytochem, 15, 409-412.

[20] Spicer, S. S. (1965). Diamine methods for differentiating mucosubstances histochemically. J. Histochem Cytochem, 13, 211-234.

[21] Spicer, S. S. Horn, R. G., and Leppi, T. J. (1967). Histochemistry of connective tissus mucopolysaccharides. In The connective tissue, pp. 251-303. Wagner, B. M., and Smith, D. E. (eds.). Williams and Wilkins, Baltimore.

[22] Tajima, N. (1986). Lectin staining on carcinoma of gallbladder and mucosa of chronic cholecystitis. Nippon Shokakibyo Gakkaishi, 83, 2393-2401 (in Japanese with English abstract).

[23] Tatematsu, M., Ichinose, M., Miki, K., Tatematsu, K., Kishikawa, H., and Ito, N. (1988). Gastric phenotypic expression in human gallbladder cancers revealed by pepsinogen immunohistochemistry and mucin histochemistry. Virch Arch, A 413, 25-32.

[24] Terada, T. and Nakanuma, Y. (1988). Morphological examination of intrahepatic bile ducts in hepatolithiasis. Virch. Arch. A 413, 167-176.

[25] Terada, T., Nakanuma, Y., and Ohta, G. (1987). Glandular elements around the intrahepatic bile ducts in man ; their morphology and distribution in normal livers. Liver, 7, 1-8.

[26] Wahlin. T. (1979). Histochemical analysis of mucosubstances and cytochemical studies of the Golgi region and the secretory granules of the normal gerbil gallbladder principal cells. Acta Anat., 103, 468-476.

[27] Womack, N. A., Zeppa, R., and Irvin, G. L. (1963). The anatomy of gallstones. Ann Surg., 157, 670696.

[28] Yonezawa, S., Nakamura, T., Tanaka, S., Kuroki, K., and Sato, E. (1985). Lectin histochemistry of a case of ulcerative colitis complicating rectal carcinoma. Acta Pathol Jpn, 35, 1571-1579. 


\title{
正常スナネズミ胆管系の組織化学的研究
}

\author{
板垣慎一・ミゲル A . ペトゥルチェリ・土井邦雄
}

東京大学農学部実験動物学教室

正常スナネズミ胆管系を組織化学的に検索した。胆管
と胆衰の上皮細胞の腔側細胞膜および細胞膜下の細胞 質は, 過ヨウ素酸シッフ (PAS), アルシアン・ブルー $\mathrm{pH} 2.5(\mathrm{AB})$ および高鉄ジアミン $\mathrm{AB}$ 染色に陽性を呈 し, 核上部に PAS 弱陽性顆粒状物質が認められた。 レクチン組織化学的には、本細胞は, Concanavalia ensiformis (Con A), Dolichos biflorus (DBA), Glycine max (SBA), Ulex europeas-I (UEA- I ) および Triticum vulgarus (WGA) に対する結合部位
を有していた。一方, 胆管周囲腺の上皮細胞は上記のい ずれの染色に対しても陰性であった。以上の光顕的検索 結果ならびに過ヨウ素酸メセナミン銀およびレクチン (DBA，WGA) を用いた電䫓的検索結果から, 正常ス ナネズミの胆管系では胆管および胆衰の上皮細胞が末端 シアル酸・硫酸基を持つムチンを分泌して扣り,このム チンのレクチン組織化学的性状は，マウスやラットの胆 管周囲腺の上皮細胞から分泌されるムチンのそれと同様 であることが示唆された。

\section{Explanation of Figures}

Figs. 1-8. Gallbadder $\times 180$. Luminal surface membrane and apical cytoplasm of epithelial cells are positive by various histochemical stainings (Figs. 1-7, 8b). Intracytoplasmic granular material is also clearly positive by some stainings (arrowheads) (Figs. 3, 4, 6). Fig. 1. PAS staining

Fig. 2. HID-AB staining

Fig. 3. Con A staining

Fig. 4. DBA staining

Fig. 5. SBA staining

Fig. 6. UEA-I staining

Fig. 7. WGA staining

Fig. 8. a) PNA staining

b) PNA staining after neuraminidase digestion

Fig. 9. Gallbladder epithelial cell. Luminal surface membrane (small arrowhead), rER (large arrowhead), vesicles (small arrow) and
Golgi apparatus (large arrow) are positive. PAM method. Bar $=0.5 \mathrm{um}$.

Fig. 10. High magnification of a part of cell in Fig. 9. Trans cisterna of Golgi apparatus, sacculi and vesicles near cisterna are positive. PAM method. Bar $=0.5$ um.

Fig. 11. Epithelial cell of common bile duct. Vesicles within bleb are positive. PAM method. Bar $=0.5$ um.

Fig. 12. Epithelial cell of common bile duct. Gold particles are seen in villi and vesicles. Golgi area is negative (arrowhead). ABG method for WGA. Bar $=0.5 \mathrm{um}$.

Fig. 13. Epithelial cell of common bile duct. Gold particles are seen in villi and vesicles. ABG method for DBA. Bar $=0.5 \mathrm{um}$.

Fig. 14. Epithelial cell of common bile duct. Many gold particles are seen in Golgi area. $\mathrm{ABG}$ method for DBA. Bar $=0.5 \mathrm{um}$. 

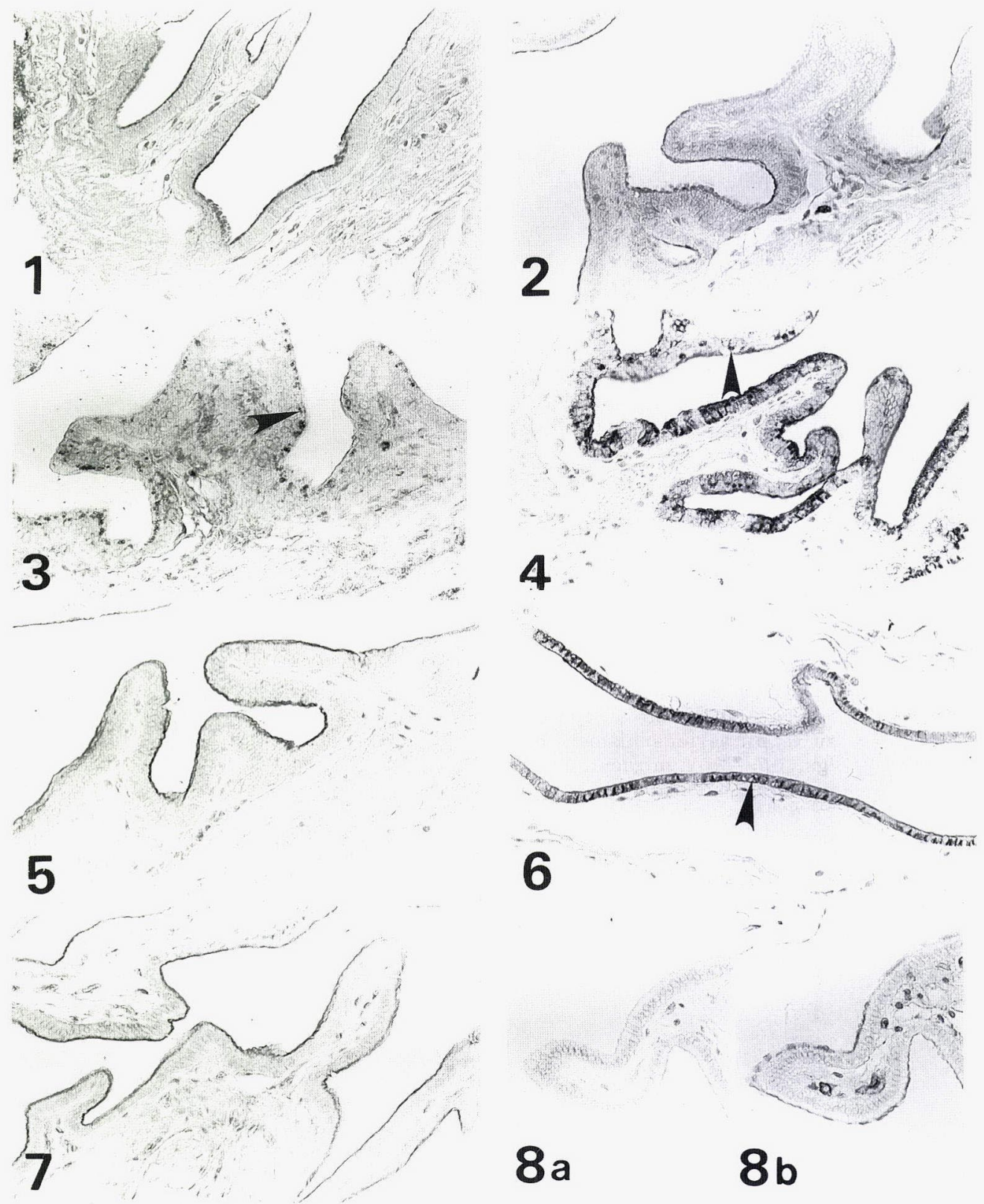

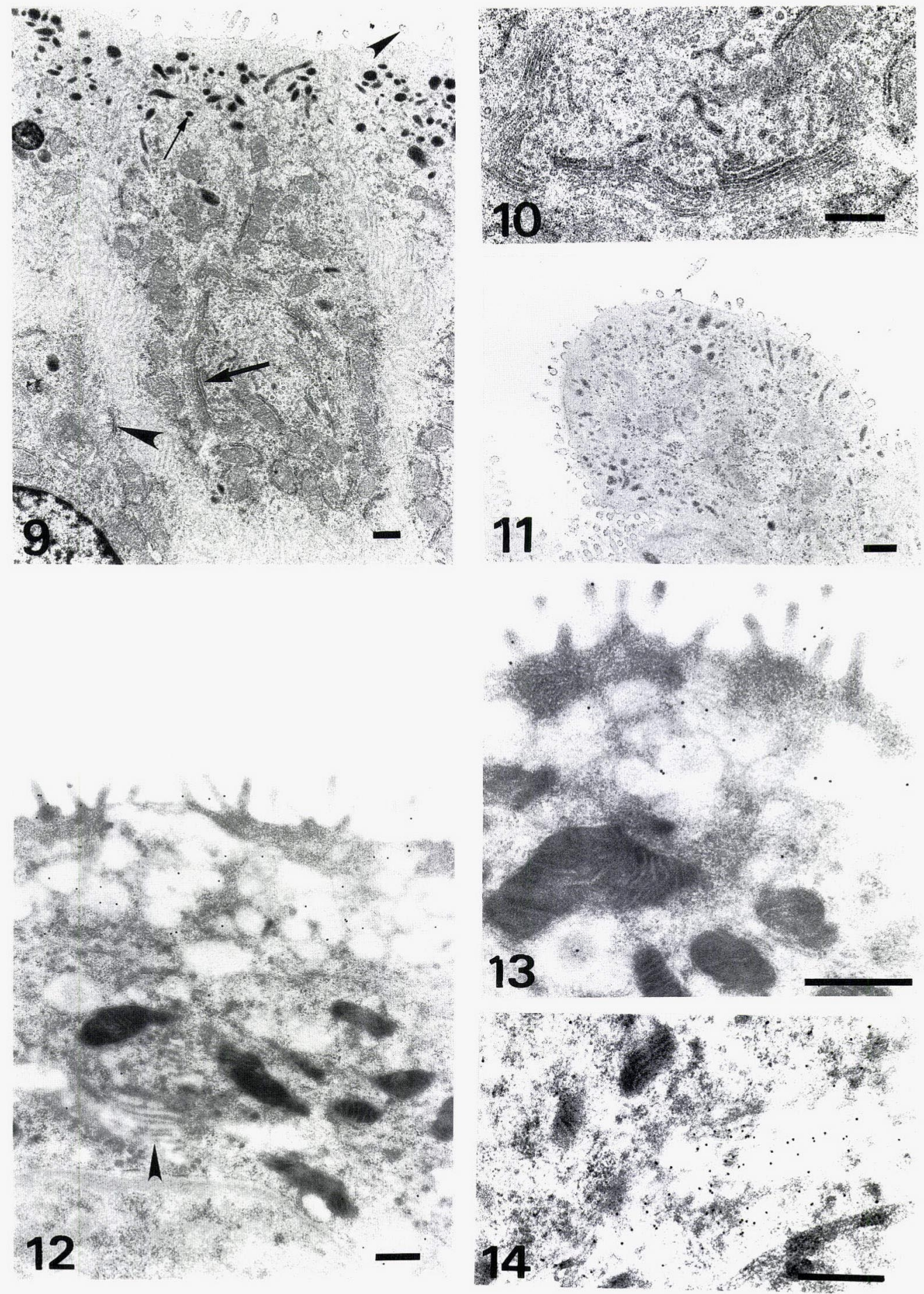